SEFAD, 2016 (36): 507-530

ISSN: 1300-4921/e-ISSN: 2458-908X

DOI Number: http://dx.doi.org/10.21497/sefad.285499

\title{
KAMUSAL ALANDA DÖNÜŞEN YAPILAR: AGORADAN SANAL UZAMA*
}

\author{
Yrd. Doç. Dr. Hatice BUDAK \\ KTO Karatay Üniversitesi Sosyal ve Beşerî Bilimler Fakültesi \\ Sosyoloji Bölümü \\ hatice.budak@karatay.edu.tr
}

\section{$\ddot{O} z$}

Yasa koyucuları edilgen bir kimlikle onaylayan yakın geçmişin bireyleri bugün kendi yorumlarının gücüne dayanarak etken bir aktör olma mücadelesine girmişlerdir. $\mathrm{Bu}$ mücadele kamunun bir değer olarak görülmesi ve kamusal taleplerin yapıcı ve bütünleştirici bir demokrasi içinde karşılanması adınadır. Aynı zamanda devlet ve toplum arasındaki ilişkide bireyin minimalize edilerek silikleşmesi ya da marjinalleştirilerek dışlanması ile "ortak bir yaşam alanı"na kavuşmayı engelleyen sorunları çözme amacını da taşımaktadır. Bu niyet üzere yürütülen entelektüel çaba demokrasi ve kamusal alan ilişkisini geliştirecek her bir aracı akademik tartışmalara ekleyerek çözümlemektedir. Bu çözüm sürecinde ele alınan yeni medyanın konumu menfi ve müspet bir yayılım göstermektedir. Yeni medya, görme merkezli iletişim yapısıyla kamusal iletişimin söz-konuşma ilkesini zorlarken bireylerde bu yeni dile ayak uydurmaya çalışmaktadırlar. Yeni medya platformlarında bireyler kimliklerinin bir gösteri nesnesine dönüşmesini engelleyecek mümkün yolları ararken aynı zamanda politik bir aktör olarak konuşma ve eylem birlikteliğine dayalı iletişimi kuracak ve sürdürecek formülleri de aramaktadır. Bu çalışmada, yeni medyanın devlet ve toplum arasında kamusal bir alan olma olanakları ilgili literatür üzerinden tartışlarak mevcut durum betimlenmiş ve birtakım önerilerde bulunulmuştur.

Anahtar Kelimeler: Kamusal alan, karşıt-kamusal alan, yeni medya.

* Bu makale, Doç. Dr. Ertan ÖZENSEL danışmanlığında tamamlanan Yeni Çă̆ Yeni Medya ve Mahremiyetin Yeni Sınırları başlıkı Doktora tezinden üretilmiştir. 


\section{TRANSFORMING STRUCTURES IN PUBLIC SPHERE: FROM AGORA TO VIRTUAL EXTENSION}

\section{Abstract}

The individuals of the near past approving the law makers with a passive identity today have been trying to be the active actors by getting power from their own comments. This battle is for the public to be accepted as a value and on the behalf of suplying the public demands through a positive and integrative democracy. It also has the aim of solving the problems that prevent the individual from reaching "a common life atmosphere" by graying him through minimizing or excluding him through marginalizing. With this aim, the sophisticated effort analyzes every means that will improve the relationship between democracy and public sphere by adding them into academic discussions. The location of the new media in this solution process has shown a positive and negative spread. While the new media is compelling the word-speech principal of the public communication with its visual interaction, individuals are trying to get accustomed to this new language. In these new media platforms, individuals are trying to find the formulae for building and maintaining the communication based upon the togetherness of speech and action while, as a politic actor, looking for the possible ways of restraining their identity from turning into a show object. In this study, the current position of the new media has been determined by discussing its possibility to be a public sphere between the state and the society in the related literaure and some suggestions have been asserted.

Keywords: Public sphere, counter public sphere, new media. 


\section{GíRiş}

Tarihsel gelişim evrelerinin toplaminda kamusal alan, kamuyu (herkes) ilgilendiren meselelerde özel şahıslar olarak sürece dahil olan katılımcıların eleştirel akıl yürütme biçimi ile tartıştıkları, şiddet yerine ikna yoluyla ortak bir karara vardıkları devletle toplum arasında var olan bir alandır.

Kavrama genel tanımı içinden baktığımızda kamusal alan, Antik Yunan'ın doğrudan demokrasi modeli için ne ifade ediyorsa günümüz modern demokrasileri için de aynı anlama gelmektedir. Bu anlam, kamusal alanın siyasi iktidarın karar ve eylemlerine meşruiyet sağlama işlevine gönderme yapmaktadır. $\mathrm{Bu}$ nedenle kamusal alan öncelikle siyaset biliminin argümanları ile analiz edilen bir kavramdır.

Antik Yunan pratiğinde kamusal ve özel alan arasındaki sınırların, işlevlerin, aktörlerin net olması nedeniyle o dönem literatüründe çok fazla teorik tartışmanın yapılmadığını söylemek mümkündür. Bu felsefi suskunluk Ortaçağ boyunca devam etmiştir. Ancak 17. ve 18. yüzyılda Batı coğrafyasında yaşanılan iktisadi, siyasi, sosyal değişimler kamusal-özel alan ayrımına da sirayet etmiş, bu iki alan arasındaki sınırların bozulmasına, birbirlerine olan değersel konumlarının değişmesine neden olmuştur. Kamusal-özel alan arasındaki belirsizliklere toplumların demokrasi talepleri de eklenince bir sarmal hâlini alan konu, 17. yüzyıldan günümüze farklı kamusal alan modelleri içinde çözümlenmeye çalışılmıştır.

Kamusal alan tartışmaları, öncelikle sosyopolitik mücadelenin arenası olarak kabul edilen alanın sınırları, kimi ve neyi içerip içermeyeceği sorunsalı etrafında ele alınarak cevaplanmıştır. 1990'lara gelindiğinde ulusal ve küresel çapta yaşanılan dinamizme modern kamu modeli karşllk verememiştir. Globalleşme ile toplumsal ilişkilerin çokkültürlü niteliğinin açığa çıkması, farklı kültürlerin siyasi temsillerini sağlayacak yeni mekanizmalar üzerinde düşünmeyi gerektirmiştir. Aynı zamanda üniversite, sendika, parti gibi geleneksel kamusal alanlarda yaşanılan çözülmeler ile kitlesel olarak kamusala ve siyasete olan ilginin azalması günümüz temsili demokrasilerinde kriz noktaları oluşturmuştur. Bu krizleri aşabilecek, devlet ve piyasa hegemonyasından özerk kamusal alanlar oluşturma düşüncesi çağdaş demokrasi kuramları açısından büyük önem taşımaktadır.

Bugün için kamusal alanın önemi, devlet-toplum ilişkisinin demokratikleştirilmesi idealine sağlayacağı somut katkıdandır. Günümüzde siyasal erkin/devletin sadece 'hukukun üstünlüğü' ilkesi ile denetlenmesi yeterli değildir. Devlet-toplum ilişkisinin demokratikleşmesinde karar alma süreçlerine katılımı ve tabandan denetimi sağlayacak kamusal alana ihtiyaç vardır. Böyle bir kamusal alanın mevcudiyeti günümüz demokrasilerinin meşruiyet problemini çözmeye yardımcı olacaktır. 
Günümüz modern-siyasal kamusallığına yöneltilen eleştiriler ekseninde şekillenen karşıt kamusal alan modelleri, ilgilerini demokrasinin dördüncü kuvveti olarak kabul edilen medya üzerine yoğunlaştırmışlardır. İnternetin keşfi, bilişim ve iletişim teknolojilerindeki gelişmelerle oluşan yeni medya, bugün geleneksel medyanın temel işlevlerine eklenmenin ötesinde birtakım özelliklere sahiptir. Yeni medya, bireylerarasında senkron veya asenkron iletişimi çift yönlü kuran, etkileşim sınırlarını verili fiziksel coğrafyalardan global ölçeğe taşıyan, bireylerin içerik üretimine aktif katılımını sağlayan yapı ve işlevleri ile 'kamusal alan' tartışmalarına bir alternatif olarak dahil edilmiştir.

'Kamusal alan'dan murat sosyopolitik hayatı yönlendirebilecek 'kamuoyu'nun oluşabilmesidir. Kamuoyunun oluşabilmesi ise bireylerin haber kaynaklarına ulaşması ve ilgili konuya dair yeterli enformasyona sahip olmalarına bağlıdır. Kamuoyunun ihtiyaç duyduğu bilgiye ulaşmada iletişim araçları her zaman önemli olmuştur. Geleneksel medyanın üstlendiği rolü paylaşan yeni medya, yalnızca haber ve bilgi akışını sağlayan bir araç olarak değil internet dolayımlı kamusal alan olarak da ele alınıp değerlendirilmektedir.

1960'lardan itibaren medya ve kamusal alan ilişkisini açıklamaya çalışan yaklaşımlar medyanın çelişkili ya da çift değerli karakterini dikkate almak zorundadırlar. Nitekim yeni medyanın müspet ve menfi yönlerinin analizinden elde edilen sonuçlar ile kamusal alan olma potansiyeli doğru bir şekilde kritik edilebilir.

Bu çalışmada; yeni medyanın hem çift değerli, dikotomik karakteri hem de zamansal ve teknik olarak gelişim evrelerini tamamlamamış olması dikkate alınarak yeni medya-kamusal alan ilişkisi hakkında kesin bir yargıya varma konusunda (şimdilik) septik bir tavır tercih edilmiştir. Çalışma boyunca; yeni medya iktidar seçkinlerine karşı bireylerin ortak bir dil ile mücadele edebilecekleri ortak bir alan olma potansiyeline sahip midir? Bu sahipliğin sınırları, artı ve eksileri nelerdir? Yeni medya egemen yapıların siyasi, ticari, kültürel hegemonya ve sömürge ilişkilerini pekiştirmeye mi yoksa tekil bireylerin tekilliklerini yitirmeden bütünleşmelerine, toplumsal yaşama müdahil olabilmelerine mi hizmet edecektir? soruları etrafında yeni medyanın kamusallık potansiyelini çözümlemek, kamusal alan-demokrasi ikilisinde yeni medyanın konumunu tespit etmek ve mevcut durumu betimlemek amaçlanmıştır.

\section{KAMUSAL ALAN KAVRAMI}

Kamu ve kamusal kavramlarının günlük dildeki kullanımı, kavramların birbirleri ile örtüşmeyen çeşitli anlamlara sahip olduklarını göstermektedir. Tarihsel süreçten kaynaklanan bu anlam farklllkkları, sadece gündelik dilin değil başta hukuk, siyaset, sosyoloji olmak üzere bilimlerinde kavramlar ile ilgili geleneksel kategorilerin yerini alacak kesin belirlemeler yapamamasından kaynaklanmaktadır 
(Habermas 1997: 57). Bütün bu farklllıklar ve belirsizlikler içinden kamusal alan kavramını tanımlayacak anahtar ve ortak sözcükler bulmak da mümkündür.

Batı'da Antikçağ Yunan topluluklarından beri kullanılagelen kamu kelimesi sözlük anlamı itibariyle herkes, kamusal alan kelimesi ise (Grekçesi politikos, Latincesi republices, Osmanlıcası amme) genelde özel ve siyasal alan dışında kalan ve herkes için ortak alan demektir (Aydın 2002: 77).

Kamu kelimesinin İngilizcede bilinen ilk kullanımı (1470'te) "kamu"yu toplumun ortak çıkarı ile bir tutmaktır. Yetmiş küsür yıl sonra (1542'de), bu tanıma sözcüğün "genel gözleme açı ve ortada olan" şeklinde yeni bir anlam daha eklenmiştir. 17. yüzyıl sonlarına gelindiğinde "kamu ve özel" karşıtlığının bugünkü kullanımına yaklaştığı görülmektedir. "Kamusal" sözcüğü görece çok çeşitli insanları içine alan, herkesin denetimine açı olan anlamına gelirken, "özel" sözcüğü kişinin ailesi ve arkadaşları ile sınılanan mahfuz bir yaşam bölgesi anlamina gelmektedir (Sennett 1996: 31).

S. Benhabib, H. Arendt'in kamu alanı kavramını, agonistik (rekabetçi) ve birleşimsel terimleriyle çift yönlü olarak açıkladığını belirtmektedir.

Agonistik görüsse göre kamu alanı, ahlaki ve politik büyüklüğün, kahramanlığın, seçkinliğin açığa çıktığı ve insani olan her şeyin geçiciliğine karşı ölümsüzlük aranılan bir yerdir. Birleşimsel görüşe göre ise kamusal alan, insanların uyum içinde hareket ettikleri her yerde ve her zaman ortaya çlkan bir yerdir. Böyle bir alan topografik ya da kurumsal anlamda bir yer olmayıp özgürlüğün kendisini gösterebildiği bir yerdir (Benhabib 1996: 241).

J. Habermas içinse kamusal alan kavramıla, her şeyden önce, toplumsal yaşamımı içinde, kamuoyuna benzer bir şeyin oluşturulabildiği bir alanı kastederiz. Bu alanda bütün vatandaşlar, genel yarara ilişkin meseleler hakkında toplanma, örgütlenme, kanaatlerini ifade etme ve yayınlama özgürlükleri garantilenmiş olarak tartışabildiklerinde kamusal bir gövde biçiminde davranmış olurlar ve kamusal alanın varlık kazanmasını sağlarlar (Habermas 2015: 95).

Antik Yunan geleneğinde görüldüğü üzere modern kamusal alan teorilerinde de kamusal alan öncelikle siyasal bir hüviyetle tanımlanmıştır. Kamusal alanı siyasalla ilişkilendirme terimin birçok dilde devleti ve devlete ait kurumları çağrıştıran yan anlamlar kazanmasına neden olmuştur. Bu çağrışım kısmen geçerli kabul edilebilir ancak ilke olarak kamusal alan devlet dışı bir yapılanmadır. $\mathrm{Bu}$ nedenle Habermas' in söylemlerinden hareketle M. Özbek, devlet gücünün kullanıldığı kurumsal yerleri kastederken "kamu erkinin (otoritesinin) alanı" kavramının tercih edilmesini; (politik) kamusal alan kavramının ise "demokratik katılım ve eleştirel söylem alanı" olarak kullanılmasını önermektedir (Özbek 2015a: 35). 
Kavrama yüklenen çeşitli anlamların paralelinde bu çalışmada kamusal alan kavramıyla bireylerin sosyal statü, sınıf, cinsiyet vb. farkllılılardan arî eşitler olarak özgür ve aktif bir biçimde katıldıkları, söz, tecrübe ve eylem mekânı olarak mevcut sosyopolitik yapıda şiddete değil iknaya dayalı mücadele ve müdahale ile dönüşüm yaratma gücü taşıyan bir alan kastedilmektedir.

\section{KAMUSAL ALANIN GELIŞiMi VE FARKLILAŞAN YAPILAR}

İnsani yaşamın temel kavramlarından biri olarak kamusal alanın ne olduğuna ilişkin teorik ve pratik veriler Antik döneme aittir. Antik Yunan pratiğinde kamusal ve özel alanın yapısı, bu yapı içinde yer alan aktörlerin kimliği ve üstlendiği işlevler zaman içinde farklılaşmıştır.

Yunan düşüncesinde polis, (siyasal/kamusal alan) özgürlük sahası iken hane, (özel alan) yaşamın devamlılığı için gerekli faaliyetlerin sürdürüldüğü zorunluluklar alanıdır. Bu iki alan arasındaki net ayrışmada olası tek ilişki poliste özgürlüğü elde edebilmek için bireyin hanedeki yaşam zorunluluklarından kadın, köle, çocuklara sahip olma ile muaf olabilmesini sağlamaktır (Arendt 2013: 68). Yunan bilincinde kamu, yaşamı sürdürmek için katlanılan mahrumiyetler nedeniyle utanç duyulan özel alan karşısında özgürlük, eşitlik, istikrar alemi ve bireye şanının ölümsüzlüğünü sunan bir alandır (Habermas 1997: 60).

Bu açıdan Yunan'da kamusal alanın insanı motive eden iki temel niteliği vardır. Birincisi özel alanda biteviye uğraştığı, biyolojik döngüyü tamamlamak zorunda olduğu emek harcama, çalışma safhasından kurtulmak. İkincisi, kendini sınama alanına dahil ederek eyleminin yankısını görebilmektir (Şen 1998: 65).

Özetle Antik dönemde kamusal alan, yaşamsal zorunluluklardan kurtulmuş olmaları nedeniyle özgür olan bireylerin sözle (lexis) buluştukları ve eylemleriyle (praxis) hem siyasi hem de erdem alanında ölümsüzlük kazandığı bir alandır. Özel alan ise içinde iktisadi faaliyetlerinde yürütüldüğü, hane içi zorunlulukların ve mahrumiyetlerin hakim olduğu, hane reisinin kamusal alandaki mevcudiyeti için gerekli ama aynı zamanda hor görülen bir alandır.

Yunanlıların yorumuyla kişinin farkını ortaya koyarak başkalarından üstünlüğünü gösterebileceği (Arendt 2013: 90), onur kazanilabilen serbest bir alan olan kamu modeli Ortaçağ boyunca Roma hukukunda 'res publica' olarak gelenekselleştirilerek devam etmiştir.

Roma döneminde (Yunanın polisine karşllık) 'republicus' ile karşılanan kamusal ayrı bir öneme sahiptir. Bu dönemin dikkat çeken iki özelliği vardır: Birincisi kamusal ile özel oldukça paralelleştirilmiş; ikincisi ise Yunan sitelerinde seküler bir içerik taşıyan kamusal mistik bir nitelik kazanmıştır. Böylece Hıristiyanlık inancı kamusalın salt siyasal bir nitelik kazanmasını önleyebilmiştir (Aydın 1998: 109). 
Erken Ortaçağ (5-6. yy.) ve Geç Ortaçağın feodal toplumunda gelişen temsili kamusal alan doğrudan bir yöneticinin somut varlığına bağlıydı. Temsili kamu döneminde kamu halkın bütününü ve söz sahibi olmasını değil doğrudan iktidara işaret etmiştir. Siyasi ve ekonomik iktidarın kamusal temsili reform dönemine kadar devam etmiştir (Habermas 2015: 97).

15. yüzyılda başlayan Rönesans, feodalitenin çözülmesiyle sonuçlanmıştır. Rönesans'tan sonra aristokrasi toprak egemenliğinin temsil gücünü yitirmiştir. Bu dönemde erken kapitalist mübadele iktisadının gelişmesiyle ulusal ve bölgesel devletler ortaya çıkmış, temsili kamu saraya sıkışarak devletle toplum ayrılmıştır (Habermas 1997: 70). Bu şartlarda gelişen burjuva kamusal alanının aktörleri kamusal otorite ile fikir mücadelesine girmeye başlamıştır. Ancak bu mücadele iktidarı paylaşmaya değil tam tersine iktidarı denetleme ilkesini gerçekleştirmeye yani devlet işlerinin kamusal kılınmasına yöneltilmiştir (Habermas 2015: 98-99).

17. ve 18. yüzyılda Paris, Londra gibi büyük şehirlerde yaygınlaşan salon ve kahvehanelerde okudukları üzerinden birbiri ile tartışan yazarlar, soylular ve burjuva edebi kamunun oluşumunu sağlamışlardır. 17. yüzyılın sonlarında basın, haber ve bilgive herkesin düzenli bir biçimde ulaşmasını sağlayarak bu oluşumda etkili olmuş daha önceleri tartışılmayan konuları kamuya taşımıştır. Bu bağlamda edebi kamu burjuva kamusunun temel niteliği olan siyasallığa zemin hazırlamıştır (Habermas 1997: 100-101).

Modern siyasal düşüncenin yaygınlık kazandığı 18. ve 19. yüzyıl kamusalı, bireylerin her türlü farklılıklarını özel yaşam alanına bıraktığı, eşit hukuksal statüye sahip olduğu, vatandaş sifatıyla devlet nezdinde bir kimliğe kavuştuğu homojen bir kamu olarak ön plana çıkmıştır (Çaha 1998: 78). Bu bağlamda burjuva kamusallığı, Aydınlanma ideali çerçevesinde rasyonellik açısından bir ilerlemeyi temsil etmektedir. Çünkü siyasal erkin eylemlerini kendinden menkul olmaktan veya bir sınıfın çıkarlarına hizmet etmekten kurtarıp meşruiyetin kaynağını insan hakları ve rasyonel uzlaşma ilkelerine bağlamıştır.

Habermas'ın idealize ettiği burjuva kamusal alanı 18. yüzyıl itibariyle yapısal dönüşüme uğramaya başlamıştır. Kamusal alanın yapısal dönüşümünde etkili olan birincil unsur Habermas'a göre; liberal rekabetçi kapitalizmden tekelci kapitalizme geçiş sürecinde yaşanılan gelişmelerdir. Bu çözülme sürecinde devletin topluma müdahalesi arttıkça kamusal alan devletin karşısında konumlanma, herkese açık olma, özel çıkarlardan bağımsızlık, eleştirellik gibi temel niteliklerini kaybetmeye başlamıştır (Hasdemir-Coşkun 2008: 129).

Tarihi gelişmeler ve kırılmalar paralelinde farklı açılımlarla ördükleri fikirlerinden faydalandığımız Habermas, Arendt dahil bütün düşünürler, kamusal alanın 'politikanın kabı' olduğu konusunda anlaşmaktadırlar (Özbek 2015a: 87).

Günümüzde ise kamusal alan denildiğinde sadece politik değil kültürel pratikleri de içeren bir alandan bahsedilmektedir. Kamusal alan, kültürel gözlükle 
baktığımızda toplumsal tecrübemizin ufuklarını belirten bir kavram, politik bir gözlükle baktığımızda ise özgürlük ve adalet mücadelesinin yapıldığı söylem ve eylemin alanıdır. Dolayısıyla günümüzde tekil, genel kamusal alandan ve içindeki kamusal alan parçalarından bahsedilen, kompleks bir yapıya vurgu yapılmaktadır (Özbek 2015a: 56).

$\mathrm{Bu}$ oluşumu J. Keane, kamusal hayatın "yeniden feodalleşmesi" biçiminde ancak Habermas'ın kullandığı anlamdan farklı olarak olumlu bir nitelendirmeyle (Kejanlıŏlu 2015: 847) okumaktadır. Bu çoğul kamular gerek kendi aralarında gerekse egemen kamular arasında söylemsel bir iletişim ile siyasal hayatın demokratikleşmesine katkı sağlayacaktır. Çünkü 1990'lardan itibaren soyutlamaya dayalı kamusallı anlayışı ciddi bir dönüşüm geçirmiş, daha fazla katılım anlayışıla gelişen somut kamu, farklılıkların aleniyet kazandığı, kendi özgüllüklerinde gelişmeye devam ettiği bir alana doğru evrilmeye başlamıştır (Çaha 1998: 79).

Modern kamusal alan modellerinin "ortak iyi"ye ulaşma çabasında ssrarla savundukları monist, dışlayıcı, homojen, rasyonel ve seküler dil günümüzün gerçekleriyle çakışmakta, toplumsal taleplere cevap verememektedir. Hâlbuki kamusal alan kavramının önemi demokrasi talebiyle kesişmesinden kaynaklanmaktadır. Zira "kamusal alanda bireyler arasında tartışmaya açık eylemin yitirilmesi özde pasif, politikadan uzaklaştırılmış (depolitize edilmiş) bir yurttaş kitlesini" (Villa 1996: 269) doğuracaktır.

Bugün kamusalın en önemli sorunlarından birisi, siyasallaşmı̧ bir kamusal karşısında sivil toplum örgütlerinin merkezi yapı içinde karar alma ya da denetim süreçlerine katılımının zayıflatılmış olmasıdır. Böylece iktidar sahipleri ile kamu arasındaki diyalog ve uzlaşı mesafesi artmaktadır.

Bununla birlikte içinde yaşadığımız çağda kamusal alan yalnızca yasalar yapmak, oy vermek, eşit oy hakkına sahip olmak, partiler kurmak, örgütlenmek değildir. Asıl önemlisi bunlar varken birbirini boğazlamadan politik ve ideolojik bir mücadele verebilecek şartların yaratılabilmesidir (Ünüvar 1998: 190). 18. ve 19. yüzyılın genel irade altında vücut bulan homojen kamusundan dönüşen günümüz kamusal alanı çoğulculuk ethosunun yaşama geçirildiği bir mekân olma potansiyeline sahiptir. Çoğulculuk ethosu temelinde örgütlenmiş kamusal alan, toplumsal kimliklerin 'demokratik özne konumuna' dönüşmesinin ön-koşuludur (Keyman 1998: 66). Bugün kamusal alan kavramı her şeyden fazla bunu imlediği için önemlidir.

\section{AĞ TOPLUMUNUN KAMUSAL ALANI: YENI MEDYA MI?}

Tarihi kökeni Antik Yunan'a dayanan ancak Aydınlanma felsefesinin idealleri ile modern şeklini alan kamusal alanın varlığı özgür kamusal iletişimin varlığına dayanmaktadır. Kamuoyunun teşekkülü için gerekli olan kamusal iletişimin mümkünlüğü ise, kamusal bilginin ortaya çıkmasını, iletilmesini ve 
etkinliğini sağlayacak belirli iletişim araçlarına bağlıdır (Timisi 2003: 142). Bu bağlamda internetin toplumun özgürleşmesi ve demokratikleşmesini sağlayacak kamusal bir iletişim aracı olup olmadığı tartışılmaktadır.

M. Özbek'e göre yeni medya araçları, kamusal iletişimi mümkün kılarak modern dünyada kamusal bilgi ve kamuoyunun oluşumunda giderek artan bir etkiye sahiptir. Topluma iletişim merceğinden bakıldığında kamusallık, sadece eleştirel akıl yürütmek değil, ortak duyusal algılama, itaat, itiraz, isyan, çatışma, anlaşma, tanıma, dayanışma, süreçlerini de içeren iletişim biçimlerine dayanmaktadır (Özbek 2015b: 603). Bu bakış açısından değerlendirildiğinde yeni iletişim teknolojileriyle şekillenen kamusal ilişkiler ağı farklı kamusal alanlar doğurmaktadır.

Yeni medya ve kamusal alana dair yürütülen iki taraflı tartısmaların kilit noktalarından biri 'mekân' öğesidir. Kamusal alanın sınılarının net bir şekilde çizildiği dönemlerde 'mekân' öğesi belli fiziksel bir alana tekabül etmektedir. Antik Yunan'dan burjuva kamusallığına ve oradan günümüze geldiği hâliyle kamusal alan olarak adlandırılan mekânlar kent meydanı, pazar yeri, agora, kahvehaneler, salonlar, sanat galerileri, tiyatrolar, konser salonları, yayınevleri, sosyal kulüpler, akademiler, üniversiteler, meclis ve mahkemelerdir (Ünüvar 1998: 190).

Geleneksel yaklaşımlarda kamu ulusal sınırlar içinde bir alana denk düşmüştür. Günümüzde ise iletişim endüstrisinin giderek küreselleşmesi ve ulusüstü olması, kamu kavramının toprağa bağlı (territorial) bağını giderek azaltmaktadır (Hansen 2015: 146). Dolayısıyla kamusal alan belirli bir fiziksel coğrafyayı ve bu coğrafyanın insanlarının ilgi sınırlarını aşarak küresel bir ölçeğe yayılmaktadır. Bu bağlamda yeni medya, klasik mekân anlayışı dışında 'herkese açık olan ortak bir mekâna erişimdeki kolaylıkla' ilintili olarak 'kamusal alan' olarak değerlendirilebilir.

Ancak yeni medyanın bu mekânsız dolayım alanı ve hitap ettiği n sayıdaki aktör kitlesi de sorunludur. Yeni medya üzerinden iletişime geçen bireyler fiziksel bir aradalığın olmayışı nedeniyle aralarında yüz yüze ilişkilerde olduğu üzere bir bağ kuramazlar. Bu durum bireylerin kimlikleri üzerinde de olumsuz etkilere sahiptir. Zira yeni medya iletişiminde bireyin mevcudiyetinin fiziksel (bedenle) sunumu yoktur. Bu nedenle ağ iletişimine katılanların gerçekte kim oldukları tam olarak bilinemez. Aynı zamanda bireyler anonim bir kimlikle ya da kimlikleri üzerinde yaptıkları güncellemelerle iletişim sürecine katılabilirler. Bu sebeplerden ötürü kimi düşünürler yeni medyanın klasik kamusal alanlar olan kahvehane, üniversite, sokak $v b$. ile aynı etkiye sahip olamayacağını, bu mekânların rollerini tamamıyla üstlenemeyeceğini savunmaktadırlar (Gökçe 2012: 44).

Kamusal ve özel alan arasındaki sınırın net olduğu dönemlerde kamusal alanın aktörleri, kamusal alana dahil olma koşulları ve tartışılacak kamusal meselelerde bir başka deyişle kamusal gündemde nettir. 
Antik Yunan'da kamusal alan özgür erkek vatandaşların alanı iken kadınlar, köleler, Yunanlı olmayanlar kamusal alanın aktörleri olarak görülmezler. Kamusal alanın aktörlerine ilişkin özellikle kadın ve erkek arasında tartışılan eşit(siz)lik sorununun temeli ideolojik, politik, ekonomik ve kültürel yapılara dayanmaktadır. $\mathrm{Bu}$ sorun, tarihsel süreçte kadının konumunun ve işlevinin ev içi özel alanla sınırlandırılmasına dolayısıyla kadının kamusal alandan dışlanmasına neden olmuştur (Küçükşen 2016: 1291 ). Kamusal alanın aktörlerine dair bu dişlayıcı tavır 21. yüzyıla kadar genel hatlarıyla korunmuş, kamusal mekânlar iktisadi anlamda mülkiyet sahibi ve eğitimli kişilerin katıldığı siyasal bir alan olarak gelişmiştir. Her ne kadar modern kamusal alan teoride özel şahısların eşit katılım ilkesine dayanmakla birlikte uygulamada bu ilke kendini gösterememiştir. Çünkü "normal, 'sıradan' insanların kamusal alana katılmasını engelleyen bugün dahi tam olarak kaldırılamayan bir dizi sosyal, hukuki engeller bulunmaktadır. Ancak bu durum yeni medya ile birlikte kısmen değişmektedir" (Gökçe 2012: 49-50).

Kamusal alana katılacak aktörlerin 'kim'liğine dair kullanılan 'herkes' kavramı bütün açılımlarıyla kendini en çok yeni medyada göstermektedir. Modern kamusal alan, modern parametrelerle tanımlanmış 'kimlik'i giyinen bireylere kapısını açarken; yeni medya farklılıklarını öne çıkaran, özgünlüğünü marjinallik sifatıyla etiketlenme korkusuyla bastırmayan bireysel kimlikleri de sahiplenip bünyesine katmaktadır. Kadınların, yaşlıların, farklı sınıfların yeni medyayı kullanım düzeyleri her geçen gün artmaktadır. Dolayısıyla yeni medya modern kamusal alandan dışlananlara kamusal aktör olabilme imkânı sunmaktadır.

Bu gelişmelere rağmen yeni medyanın baş aktörlerini hâlâ genç, eğitimli, gelir seviyesi yüksek orta veya üst sınıftan erkekler oluşturmaktadır. Yeni medya dolayımlı kamusal alana katılmanın yolu bilgisayar-cep telefonu vb. teknik araçlara ve internet erişimine sahip olmaktır. Ancak dünyanın birçok coğrafyası siber kamusal alana katılım için gerekli olan teknik alt yapıdan mahrumdur. Bu argümanın karşısında yakın gelecekte bilişim ve iletişim teknolojilerinin dünya ölçeğinde yaygınlaşacağı, şu an bu imkânlardan yoksun olanlarında internet erişimine ulaşıp günlük yaşamlarında kullanacaklarını savunmak mümkündür. Fakat A. Maslow'un 'ihtiyaçlar hiyerarşisi' hatırlandığında birincil hedefleri hayatta kalabilme olan bireylerin kapitalizmin pazar arayışları paralelinde birer tüketim nesnesi olarak internet ağına eklenmelerinden önce yaşam koşullarının iktisadi ve sosyal alanda iyileştirilmesi gerektiği de unutulmamalıdır.

Yeni medya-kamusal alan probleminde çözümlenmesi gereken bir diğer husus, bireylerin kamusal alana katılım koşullarında öne çıkan özgürlük ve eşitlik ilkeleridir.

Özgürlük, Antik Yunan örneğinin idealize edildiği kamusal alan modellerinde öne çlkan kavramlardan biridir. H. Arendt'e göre 'özgürlük'ün en eksiksiz ifadesi eylemde kendini gösterir. Ama eylemin gerçekleşmesi için, bireylerarasındaki ilişkinin özgür ilişkiler olması gerekir (Berktay 2015: 709). Kamu 
alanındaki ilişkide özgürlüğün ortadan kalkması ve eylemin gerçekleşmemesi, kamusal alanı insanların yaşamlarına anlam veren bir alan olmaktan çıkarır. Kendi tecrübelerinin gücüne inanmayan bireyler için geriye gerçeğin artık dayanılmaz olduğu bir dünya kalacaktır (Demir 1998: 212).

Yeni medyada birey iletişimi başlatma, sürdürme, yönlendirme açısından özgürdür ve bu meyanda bireylerarasındaki bağın özgür ilişkilerden oluştuğu söylenebilir. Ancak yeni medya kurgusallık ile gerçeği hafifleterek yarattığı simülasyondan hipergerçek bir kamusallık oluşturmuştur ki bu kamusallığın birincil görevi, sanal iletişim, sanal paylaşım, sanal müzakere, sanal eylem zincirinde kamusal aktörü sanallaştırmaktır. Yeni medyanın bireyleri eylemde bulunmaya kanalize etmedeki yetersizliği veya isteksizliği kısaca yeni medyanın 'eylemsizlik'i 'özgürlük'ü de gölgelemektedir. Oysaki bu sanal kamusallığın dışında gerçek kamusal aktörlerden oluşan gerçek bir kamusal alanın müdahaleleriyle yönlendirilmesi, sınırlandırılması, kontrol edilmesi gereken siyasi bir otorite bulunmaktadır. Şayet yeni medyanın özgürlüğü-kamusallığı bir ekrandan diğer ekrana akan kelimeler, görseller ve tıklamalardan ibaret olacaksa yeni medya, siyasi otoritenin totaliter-baskıcı rejimlere dönüşmesinde rol oynayabilir.

Kamusal alanın teşekkülü için kamusal gündemin belirlenmesinde 'herkes'in özgür ve eşit katılımı sağlanmalıdır. 'Eşitlik' ilkesini önceleyen düşünürler, yeni medyanın bireyleri eşit statü ile iletişim alanına dahil edebilme avantajını referans alarak yeni medyayı kamusal alan olarak tanımlamaktadırlar.

H. Arendt ise toplumun yatay düzlemde homojenleştirilerek eşitlenmesinden hoşnutsuzdur. Arendt'e göre, modern dünyada eşitliğin zaferi, toplumun kamu alanını fethinden ve bireyin özel meselesi durumuna gelişinin siyasi ve yasal tescilinden başka bir şey değildir (Arendt 2013: 81).

Yeni medya mecrasında gündemi kısıtlanmamış müzakere sürecinde her birey eşit söz söyleme hakkına sahiptir. Ancak bu durumu 'kamu' için bir kazanım olarak okumak da bir hayli sorunludur. Çünkü böylesi bir eşitlik birey ve düşüncesinin farkını kitlesel bir söylem içinde eritmekte, kamusal alanda yeri doldurulamaz aktif birey anlayışını bir diğeri ile kolaylıkla ikame edilebilecek sıradan-edilgen birey anlayışına dönüştürmektedir. Statü farkları eşitlenmiş insan miktarının çokluğu da yeni medyayı kamusal alan olarak değerlendirmek için yeterli değildir. Bu bireyler yeni medyada çoğu kez söz ile konuşmakta ancak eylemsel olarak kamusal meselelerin yükünü sırtlanmaya istekli olmamaktadırlar.

Habermas'ta eşitlik hakkını önemsemekle birlikte kamusallığın 'herkese açık olma' ilkesinin her dönemin gerçekliğine uymadığının farkındadır. Yine de o, 'iletişim' yoluyla kamusal alanın sınırlarının genişletilebileceği iddiasını korumaktadır. İletişim ediminin ise belli özelliklere sahip olması gerekir. Habermas için orijini iletişim (konuşma) olan kamusal müzakerede önemli noktalar şunlardır; (a) geniş halk katılımının varlığı, (b) kamusal tartışma ve sorunlardan haberdar olma, (c) bir yargıya ulaşmak için müzakereler yapma, (d) müzakerede güç ve 
iktidar ilişkilerinden bağımsız olarak her birey için eşit koşullar oluşturma, (e) müzakere edilen konuda konsensusa ya da güvenilir bir takım sonuçlara/yargılara ulaşma (Hasdemir-Coşkun 2008: 127-131).

Habermas, sağlıklı bir kamusal iletişim için gerekli gördüğü bu ilkelerin kitle iletişim araçlarıyla tam anlamıla gerçekleşmediŏi kanaatindedir. Habermas, teknolojiye bağlı kitle iletişim araçlarıyla oluşturulacak konuşma ve müzakere sürecinde herkesin eşit katılım şansına sahip olamayacağını dolayısıyla 'özgürlük'ün kısıtlanabileceğini kabul etmektedir. Aynı zamanda kapitalist toplumlarda 'araçsalcı teknokratik akıl' sorunu ile iletişim alanındaki toplumsal normların akılcılaştırılmasının gerçekleştirilememesi sorunu sağlıklı bir iletişimin kurulup sürdürülmesini, evrensel ve akılcı bir oydaşıma imkân verebilecek katılımcı bir demokrasinin kurulmasını (Hasdemir-Coşkun 2008: 132) engelleyebilecektir.

Yeni medya, eşitlik ve özgürlük ilkelerini, idealize edildiği hâliyle karşılamada sıkıntılı olsa da demokratikleşme sürecine katkı sağlayacak birtakım avantajlara da sahiptir. Yeni medya, çok sayıda kişiden çok sayıda kişiye doğru akan bir iletişimi aynı anda tüm yerkürede yayarak tek bir merkezi olmayan, büyük holdinglerin ve devletin kontrolünden bağımsı, hayli esnek ve çoğulcu bir kamusal iletişim ve katılımın yeni biçimlerini mümkün kılabilir (Kellner 2015: 865).

Yeni medya bireylerin belli bir grup ya da örgüt üyeliği içinde sıkı bağlarla bir araya gelerek kamusal iletişime dahil olma kalıplarını değiştirmiştir. Yeni medya aracılığıyla bireyler ortak bir amaç doğrultusunda daha gevşek bağlarla ancak daha geniş bir uzamda bir araya gelerek kamusal meselelerle ilgili müzakere sürecine katılabilmektedir. Bu durum alışlagelmiş kamusal mücadele ve eylem pratiklerinden farklıdır. Bu farklılık, yeni medyanın toplumsal hareketleri oluşturma ve yönlendirme potansiyelini bertaraf etmez. Bilakis bireylerin, geleneksel kalıplardan bağımsızlaştırarak tartışmalara katılımını sağladığı için egemen yapıları zorlayacak muhalif bir kamusal alanın oluşumunu olanaklı kılmaktadır.

Buchstein'e göre yeni medyanın muhalif-ideal kamusal alana imkân tanıyabileceğini düşünenler, bu süreci dört başlıkta savunmaktadırlar: Kontrol edilemez tartışma ortamları yaratabilmesiyle otoriter rejimlere karşı bağışıklık, kolay erişim, taban örgütlenmesi sayesinde eleştirel bir kamusal alan yaratabilmesi ve evrensel erişimine açık olması (Buchstein 1997: 251'den aktaran; Yağan 2013: 129-130). Bu nitelikler, yeni medyanın kamusal gündemle ilgili daha etkin bir kamuoyu oluşturma iddiasının garantörüdürler.

Habermas ise kamusal alanda kamuyu ilgilendiren meselelerde kamuoyu oluşturabilmek ve ortak bir karara ulaşabilmek için bireylerin kendi düşüncelerini eleştirel bir tartışma sürecinde, her insan aklı için geçerli olabilecek düzeyde temellendirmek, bu şekilde aktardığı fikrin doğruluğuna diğerlerini ikna etmek ve ortak iyiye uzlaşmak (Habermas 1997: 209) gerektiğini belirtir. Habermasian teoride korunduğu hâliyle akla ve eleştiriye dayalı kamusal tartışma anlayışı 
Aydınlanma düşüncesinin ürünü olan birey inancına dayanmaktadır. Bu inanca göre eğer kişiler siyasal bilgelik ile eleştirel tartışma sürecine eşit ve özgür koşullarda girerlerse, toplumsal meseleler etrafında her seferinde ve herkes açısından adil ve rasyonel (doğru) sonuçlara varabilirler (Özbek 2015a: 44).

Yeni medya platformlarında ortalama 140 karakterle konuşan (yazışan) bireylerin 'kamusal akla' ve onun spontane sonucu 'örtüşen uzlaşma'ya ulaşmaları oldukça sorunludur ki şu ana kadar yeni medya iletişimsel bir kamusal rasyonaliteye yol açmamıştır. $\mathrm{Bu}$ sorun yeni medyada kamusal müzakere gündeminin yalnızca siyasal alanla sınılı olmamasından değil, aynı zamanda aktörlerin kimliklerinin belirsizliğinden, ifadelerini irrasyonel gerekçelerle temellendirmeye çalışmalarından, aklın aydınlığından yüz çevirmelerinden kaynaklanmaktadır.

Yeni medya-demokrasi ilişkisine olumlu yaklaşan düşünürlere göre, akılcı (rasyonel) tartışma ve konsensus ilkeleri kamusal alan adına aşırı derecede idealize edilip vurgulanmaktadır. Günümüz toplumlarında kamusal alanı mülk-eğitim-sınıf merkezli homojen ve tekil bir alana indirgemek, rasyonelliğin dışında dini, ideolojik veya moral değerlerle üretilmiş karşıt kamusal alanların görmezden gelinmesine ve bu farklı kamusal alanların oluşumunda yeni medyanın rolünün ihmal edilmesine sebep olmaktadır.

Şüphesiz ki kamusal alan-demokrasi-insanın özgürleşim sorunu tarihsel, sosyal faktörler ve insan ilişkileri dikkate alınmadan yalnızca teknolojik gelişmelerden medet umularak çözülemez. Ancak karşı kamusal alanlara olanak sağlayacak bir güç olarak yeni medya kamusal mücadeleye, insanın özgürleşmesine, demokratik bir topluma doğru ilerlemeye, dünyada tek bir sesin egemen olmadığını göstermeye katkı sağlayacaktır (Aydoğan-Kırık 2012: 68).

Bireylerin sadece siyasal seçimlerle iktidara müdahale etmelerini demokrasi için yeterli görmeyen düşünceler, yeni medyanın siyasal iktidarın sivil toplum karşısındaki güç dengesini ayarlayarak farklı fikirlerin kendilerini ifade etmelerini, karşıt fikirlerle etkileşime girmelerini böylece bireylerin doğrudan demokratik yaşama katılabilmelerini mümkün kılacağını iddia etmektedirler (Yağan 2013: 128-129). Böylece yeni medya günümüzde sermayeleşen, holdingleşen medyanın konvansiyonel duruşuna alternatif olarak katılımcı demokrasinin güçlenmesinde rol oynayacaktır (Karagöz 2013: 132).

Yeni medya ve kamusal alan ilişkisinde savunulan bir diğer husus, yeni medyanın sosyal hareketlerin oluşumu ya da örgütlenmesinde rol oynadığıdır. Yeni medya, "yakın geçmişin sistemi değiştirme veya fethetme amacından uzaklaşmış, belli hak ve taleplerin iktidara duyurulmasını amaçlayan sosyal hareketler" için işlevseldir (Karakaş 1998: 163-164). Zira kamusal alan sadece devletin egemenliğine değil, fakat aynı zamanda ticarileşmeye, metalaşmaya ve sermaye egemenliğine karşı kurulması gereken bir alandır. Böylesi bir kamusal alanın oluşumunda toplumsal hareketlere önemli işler düşmektedir. Toplumsal 
hareketler 'karşıt kamusal alan' oluşturabilmeleriyle sistemin sömürgeleştirici saldırılarına set çekip, demokratik bir baraj kurabilirler (Hasdemir-Coşkun 2008: 136).

Özellikle otoriter rejimlerin hakim olduğu devletlerde değişim yanlısı bir halk hareketinin şekillenmesinde yeni medyanın rolü, geleneksel medya araçlarının muhalif kanadının üstlendiği rolü aşabilmektedir. Çünkü neyi ne kadar yayınlayıp yayınlayamayacağı iktidar tarafından belirlenen muhalif medyanın varlığı, muhalif grupların öfkesini azaltan bir emniyet supabı olarak görüldüğü için kabullenilmektedir. Ancak yakın zamanda Arap dünyasında yaşanan olaylarda da görüldüğü üzere kitleler arasında doğrudan iletişim sağlayan yeni (sosyal) medya siyasal dengeleri değiştirebilecek bir potansiyele sahiptir (Özensel 2015: 77). Bu potansiyelin açığa çıkarılması için özellikle entelektüellere düşen görev yeni medyada kitlesel iletişimi eylemle birleştirebilecek stratejileri geliştirmektir.

Yeni medya-toplumsal hareketler ilişkisine karşı taraftan bakıldığında, devlet erkinden bağımsız bir şekilde oluşan toplumsal hareketlerin ve karşıt kamusal alanların niceliksel artısı tek başına demokratik bir kamusal alana ulaşmak için yeterli görülmeyecektir. Çünkü bu çeşitlilik, kamusal alanların kendi içine kapanıp diğerlerini görmezden gelme ve antidemokratik bir tavır ile dişlayıcı olma tehlikesi taşımaktadır. Böyle bir durumda baskıcı otoritelere galip gelebilecek genel bir kamusal alana ve kapsayıcı-genel bir karara ulaşmak zorlaşırken karşıt kamusal alanlarda toplumsal misyonlarını gerçekleştiremeden sistem içinde eriyecektir.

Yeni medya ve toplumsal hareketler ilişkisine yönelik yapılmış birçok çalışmanın sonuçlarına göre internetin herkesi birbirine yaklaştıracağı, farklı düşüncelerden bireyleri bir araya getirerek toplumsal hareketlerin çeşitliliğinden ortak bir düzleme varılacağı savı gün geçtikçe geçerliliğini kaybetmektedir. Beklenenin aksine benzer dünya görüşlerine sahip insanların bir araya gelerek, gerçek hayattaki cemaat bilincinin bir benzerini sanal ortamlarda oluşturdukları tespit edilmiştir (Çayc1-Karagülle 2014: 6377).

Y. Yağan 2013 yılında yaptığı 'Üniversite Öğrencilerinin Sosyal Medya Kullanımı ve Politik Katılım Üzerine' adlı çalışmasında benzer sonuçlara ulaşmıştır. Çalışma bulgularına göre geleneksel medya aracilığıyla kamusal alanda temsil edilmeyen grupların kısmen de olsa yeni medyada yer bulabildiği, siyasal sorunların, politik kültürün çevrimiçine taşındığı ancak interneti müzakereci demokrasi olanaklarının artması için bir fırsat olarak görenlerin beklentilerini karşılamada birkaç açıdan yetersiz kaldığı tespit edilmiştir. Katılımcıların sosyal ağlar aracılığıyla politik fikir paylaşımında yüksek oranda otosansürü tercih ettikleri, gençlerin çoğunun çevrimiçi bir eyleme ya da internet üzerinden bir sokak eylemine dahil olmadıkları görülmüştür (Yağan 2013: 145).

Yeni medya-kamusal alan ilişkisine pesimist bakış, optimist bakışın 'yeni medya, toplumsal hareketler için gerekli bilgiyi çok hızlı ve kolay bir şekilde 
iletilmesini sağlamaktadır' görüşüne de eleştirel yaklaşmaktadırlar. Çünkü her gün karşı karşıya kalınan enformasyon bolluğu içinde bilgiler çoğu kez analiz edilmeden kullanılmakta ve paylaşılmaktadır. Bu durum kullanıcıların adeta enformasyon şoku yaşamasına, bütün bu bilgi kirliliği içinde hangisinin doğruyanlıs, gerekli-gereksiz olduğunu ayırt edememesine neden olmaktadır (Güçdemir 2003: 377; Göker 2015: 409). Dolayısıyla yeni medyada var olan bilgi herhangi bir eyleme yol açmamaktadır. Sanal mecrada sunulanların her zaman eğlence formunda olması, bireyleri özel alanlarına hapsederek giderek pasifleştirmesi bağlamında yeni medyanın kamusal alan yaratma potansiyelinden yoksun olduğunu söylemek mümkündür (Özgül 2012: 4543).

Yeni medya, kullanıcı türevli içerik üretimi ve hipermetinsellik özelliği ile iletilerin çeşitliliğine katkı sağlamakla birlikte mümkün olan en kısa sürede ve basitlikle içeriklerin üretilmesini ve paylaşılmasını da dayatmaktadır. Bu durum bir süre sonra içeriklerdeki çeşitliliğin ve farkllılıların azalmasına, mesajın niceliksel değerinin arttırılmasına neden olur. Yeni medyada kamusal müzakereyi başlatacak kamusal gündem başlıkları nitelik açısından değil konuya dair mesajların çokluğu ile belirlenmektedir. Bu bakımdan herhangi bir konu hakkında oluşan kamuoyunun etkinliği sosyal yapıdaki değişime katkısı ile değil yazılanların sayısal verileriyle ölçülmektedir (Göker 2015: 405).

Yeni medyanın hız ve basitlik ile sınırladığı iletişim formatı, kamusal meselelerde bireylerin derin değil klişeleşmiş fikirlerle diyaloga girmesine, dolayısıyla anda akıp giden fikirlerin ve fikir sahiplerinin kalıcı olmamasına neden olmaktadır.

Hâlbuki H. Arendt, eğer bu dünyada bir kamusal mekân bulunacaksa bunun bir nesilliğine kurulamayacağını ve sadece yaşayanlar için planlanılamayacağını, ölümlü insanların yaşam süresini aşması gerektiğini belirtmektedir. İçinde yaşadığımı çağdan önce bireyler ölümsüzlüğü kamusal alandaki eylemleri ile yakalamak istemişlerdir. Modern çağda kamu alanının yitirilmiş olmasının belki de en iyi kanıtı ölümsüzlüğe duyulan sahici ilginin neredeyse tümüyle yitirilmiş olmasıdır (Arendt 2013: 98-99).

$\mathrm{Bu}$ açıdan yeni medya aracilığılla kamusal meselelerin çözüm sürecine katılan bireylerin konumu kendinden kalıcı bir şeyler bırakmak ve böylece eyleminin garantisiyle ölümsüzlüğe imza atmaktan daha çok görünme arzusunun ve söz söyleme becerisinin kibriyle sosyal bir ağa dahil olmaktır. Aslen bireylerde sözünün yeni medyadaki paylaşımların dolanım hızıyla anda kaybolacağının ve bu mecrada kalıcı olamayacağının farkındadır. Çünkü yeni medya " bireylerin kamusal ilgilerini zamanın sebep olduğu yıkımdan koruyabilecek bir mekân oluşturma" (Arendt 2013: 101) kabiliyetine sahip değildir. Aynı zamanda bir simülasyon ve ...mış'lar evreni olarak yeni medya kamu için sosyopolitik önem arz eden tartışmaları manipüle ederek bireye kamusal alana aktif bir aktör statüsü ile katıldığı ve tartışmalara bireysel bir açılım sağladığı hissini yaşatmaktadır. 
D. Kellner'e göre yeni medyanın kamusallığı, bireylerin salt mesajlaşarak ya da belli, klişe bilgileri dolaşıma sokarak kendilerini politik olarak yeterli görmelerinden ötürü kendi içine kapalı bir dünya hâlini alma tehlikesi taşımaktadır. Ancak D. Kellner bu tehlikenin, yeni iletişim teknolojileri ile yaygınlaşan kamusal tartışma alanlarının gerçek hayattaki politik mücadeleleri bertaraf etmesini önleyecek tedbirlerin alınması ile aşlabileceğini de belirtmektedir (Kellner 2015: 868). Bir başka ifadeyle dijital aktivizmin slocktivizm (dijital tembellik) ve clicktivizm (tıklamacılık) gibi ironik bir soruna dönüşmesi engellenmelidir. Bunun için dijital aktivizm, dijital olmayan hedeflere yöneltilmeli, 'hibrit' yapılarla yani sokakla buluşturulmalıdır (Uçkan 2012).

Yeni medyayı kamusal alan olarak değerlendirmeme nedenlerinden biri de, kapitalizmin gelişim sürecinde büyük şirketlerin kamusal alana dahil olmasında yaşanılan değişimlerdir. Kamusal alan, kavramsal olarak devletten ve resmi ekonomiden ayrı, ilke olarak devlete karşı eleştirel söylemlerin üretildiği ve satın alma-satmak yerine fikir mücadelesi ve müzakere için kurumsallaşmış bir alandır (Özbek 2015a: 30). Bu ilke üzerine yeni medya irdelendiğinde devlet otoritesinden ve denetiminden tam anlamıyla bağımsız olmadığı (internet dağıtımı ve kontrolü birçok ülkede hâlâ devletin tekelindedir) ve ciddi anlamda ticarileşerek pazar ilişkilerine entegre olduğu görülmektedir. Yeni medyanın devlet aygıtları ve ekonomik pazarlarla göbek bağını kesememiş olması bu iki alanı sarsacak eleştirel söylemler üretebilmesine gölge düşürmektedir.

Kitle iletişimin piyasa-pazarın kurallarıyla ticarileşmesi, kitlelerin kamusal katılımını sağlama işlevini ve siyasal karakterini yitirmesine neden olmuştur. Kitle iletişimine bağlı olarak genişleyen kamuda kamusal topluluk, kamusal-olmayan akıl üreten uzmanlardan oluşan azınlıklar ile kamusal alıcı konumundaki tüketicilerin oluşturduğu büyük kitle arasında bölünmektedir. Ticarileşen iletişim kitle kültürünü doğururken kitle kültürü de gücünü tüketici gruplarının eğlence ihtiyaçlarına uyum sağlayarak arttırmasından almaktadır. Böylece kültürel akıl üreten kamusal topluluktan kültür tüketen kamusal topluluğa giden yolda kitle iletişim araçlarının temsil ettiği kamusallık yalnızca görünüşte kamusaldır (Habermas 1997: 287-301). Yeni medya, bu kamusal görüntü içinde bir söylem bolluğuna işaret etse de toplumsalı, kamusalı, özel alanları yüzeysel seyirlik nesne, imaj üretim alanları, eğlence yerleri hâline (Sözen 2012: 28) getirmekle, rasyonel tartışmanın değerini azaltmakla eleştirilmektedir.

Graham Murdock'da yeni ekonomik ve teknolojik gelişmelerin getirdiği medya bolluğunun çeşitlilik ve farklılık içeren bir kamusal alan yaratmadığını iddia ederken, Meral Özbek ise teknolojik iletişim araçlarının yarattığı sanal iletişim uzamının sadece politik değil sosyokültürel açıdan da kamusal alan oluşturduğunu düşünmektedir. M. Özbek'e göre yeni medyayı kamusal yapan şey, (öncelikle eyleme ve konsensüse ulaşma hedefi değil) herkesin erişebildiği ve de olabildiği ölçüde bürokratik hiyerarşi ve baskıya direnen bir kullanım değerine sahip olmasıdır. Alexandre Kluge'un "bilgi taşımak, bilgi dolaştırarak kamusal alanın 
ufkunu genişletmek, doğrudan eylem kadar önemlidir" sözü de yeni medyanın kamusallığının salt eyleme dayandırılarak ele alınmaması gerekliliğine gönderme yapmaktır (Özbek 2015b: 624-627).

Karşıt kamusal alan modelleri için yeni medya devlet erkinin dışında bir kamuoyunun oluşumunda bilgi ve haber kaynağı olarak kullanılacak elverişli bir araçtır. Ancak yeni medya söylemsel kamu modelinin olmazsa olmaz koşulu 'rasyonel akıl yürütmeye dayalı iletişim ve müzakere sonucunda konsensüs'a ulaşma konusunda yetersizdir. Buradaki 'konsensüs' vurgusu tek tek bireylerin veya küçük grupların iktidarı etkileyebilme potansiyelinin daha zayıf olduğu (Karakaş 1998: 165) kabulünden ileri gelmektedir. Habermas'a göre bu kabul dışlayıcılık veya tek tipçilik (söylemsel kamu modeli bu bağlamda yoğun eleştiriler almaktadır) anlamına gelmemektedir. Habermas'a göre kamusal müzakereye herkes eşit ve özgür koşullarda katıldığı ve herkes kendi iradesine dayanarak herhangi bir baskı altında kalmaksızın anlaşmaya vardığı için son noktada varılan uzlaşma tekil karakterli olsa da alınan kararların meşruiyetini zedelemeyecektir (Karadağ 2003: 191).

Habermasian bir gözlükle yeni medyaya tekrar baktığımızda, siber uzamda ulusal ya da global ölçekte bir araya gelen çok sayıda kullanıcının aynı anda çoğu kez rasyonel olmayan gerekçelerle tartışması sonucunda bir uzlaşmaya veya çoğunluk kararına varmaları güç görünmektedir.

Söylemsel kamu modeli açısından yeni medyanın -mevcut hâlindeki birtakım olumsuz kullanımlar nedeniyle- Aydınlanma öğretisinin ideallerini tam anlamıyla temsil eden bir kamusal alan olarak değerlendirilemeyeceğini ancak devlet (siyaset) ile toplum arasında dolayımlı bir kamusal alanın oluşmasında geleneksel medya araçlarının yüklendiği role eklenerek katkıda bulunabileceğini söylemek mümkündür. Bir başka ifadeyle yeni medya, idealize edilen siyasal kamu alanının oluşmasında ve genişletilmesinde katılımcılar arasında kamusal iletişimi sağlayacak bir araç olarak kullanılabilir. Yeni medya teknik avantajlarına dayanarak aktörü 'herkes' olan bir tartışma ortamında rasyonel-eleştirel akıl yürütmeyi mümkün kılarak bir zamanlar edebi kamunun oluşumunda basının oynadığı rolü teknokratik çağda üstlenebilir. Bunun için yeni medyanın piyasapazar ilişkisi içinde bir tüketim mecrası olmaktan sıyrılması, iletişimi kitlesellikten arındırması, irrasyonel, yüzeysel diyalogun yükselişe geçmesini engellemesi, kamuoyunun oluşması için gerekli doğru bilgi-haber akışını sağlaması, hegemonyanın sömürü aracı olarak değil özgürleştirici bir araç olarak konumlanması gerekmektedir.

Yeni medya-kamusal alan-demokrasi üçgeninde net bir açı yakalamak şu an itibariyle zor görünmektedir. Yeni medyanın hem toplumsal etkileşimde dezavantajlarının bulunduğu hem de ana akımların ötesinde özgür düşünceye imkân sağlayan bir alan olduğu göz ardı edilmemelidir. Bu iki yön arasında yeni 
medyanın nereye doğru evrileceğini en iyi zaman gösterecektir. Ancak şu hâliyle yeni medya, insanların hipertext bir dille konuştukları dijital bir mekândır.

\section{SONUÇ}

Modern kamusal alan modelleri, Antik Yunan polisinde kendini gösteren ve tarihsel koşullarla birlikte şekillenen kamusal alan anlayışlarının nihai ilkelerini içermektedir. Klasik kamu modelleri düşün hayatına çok önemli argümanlarla katkı sağlamakla birlikte son dönemlerde ciddi eleştiriler almıştır. Bu eleştiriler, kamusal alanı ulus-devlet ve pazar politikalarını meşrulaştıran bir araç olarak kullanan modernizme duyulan hoşnutsuzluklardan kaynaklanmaktadır. Modern kamusal alan anlayışları eleştirilere kayıtsız kalmayıp, özgürlük, eşitlik, farklılık, çoğulculuk, rasyonellik, ortak yarar gibi ilkeler açısından çağın taleplerine yaklaşmaya çalışmışlardır. Ancak merkezi kavramlarında israrcı oldukları için günümüz 'kamusal alan' problemini çözmede yetersiz kabul edilmişlerdir.

21. yüzyıl, modern kamusal alan eleştirileri ile belirginleşen 'karşıt kamusal alan' kavramlaştırmalarının ve bu farklı paradigmalar arasında ateşli tartışmalarının yaşandığı bir yüzyıldır. Zira 21. yüzyıl, modern demokrasi anlayışının çokkültürlülük ve çoğulculuk normlarıyla revize edilme zorunluluğundan kaçamayacağımı gelişmelere sahne olmuştur. Demokrasi tartışmalarında kamusal alan merkezi öneme sahiptir. Kamusal alan aracilığılla farklı-karşıt fikirler arasında kurulan iletişim, siyasi otoriteyi denetleme ve katılımcı demokrasi uygulamalarını destekleyecektir. Kamusal alan, kimlik taleplerinin radikal bir çatışmaya dönüşmesini, birinin diğerine tahakkümünü engelleyecek bir dolayım alanı olabildiğinde çoğulculuk ethosunun hayat bulduğu bir alanda olacaktır.

İnsanlığın kaderi demokrasinin kaderine yazgılı ise bu buluşmada bireyin özerk kalabilmesi ve halkın kendini yönetebilmesi, toplumsal yaşama nüfuz edecek yasaların oluşumuna 'herkes'in kendi diliyle, özgür, eşit ve adil katılımına imkân tanıyacak koşulların oluşturulmasına bağlıdır. Bu çabaya katkı sağlayacak her araç kendi sınırları içinde çözümlenerek kullanılmalıdır.

Günümüz ağ toplumlarında kamusal alan-demokrasi ilişkisinde mevcut kurumların dışında alternatif yapılar oluşturma arzusu yeni medyaya olan akademik ilgiyi artırmıştır. Ancak burada yeni medyanın çift değerli, dikotomik yapısı ciddi şekilde değerlendirilmelidir. Bir iletişim aracı olarak yeni medya hem 'kamusal alan' olma potansiyelini hem de kamusal alan kavramının içini boşaltma tehlikesini taşımaktadır.

Yeni medya-kamusal alan ilişkisine olumsuz yaklaşanlar için yeni medya, siyasi otoritenin gölgesinde kalan, sermaye sahiplerinin çıarlarına hizmet eden, kâr amacı güden dolayısıyla gittikçe tecimselleşen bir alandır. Bu nedenle yeni medya, egemen yapıların baskı araçlarından biridir. Zira yeni medya siyasi-iktisadi erk karşısında mücadeleci ve müdahaleci bir kamuoyunun oluşumunu sağlayacak 
niteliklere de sahip değildir. Yeni medya internet ağı olarak topografik bir mekâna denk düşmemektedir. Yeni medya, bireylerarasında fiziksel mekâna bağlı gelişen birliktelik ve ortaklık duygularını ikame edememektedir. Ayrıca fiziksel bir aradalığın olmayışı bireyin 'kamusal aktör' kimliğini belirsizleştirmekte, söz ve eylem arasındaki bağı zayıflatmakta dolayısıyla yeni medyanın kamusallık muhtevasını daraltmaktadır.

Böyle bir konumda yeni medya, toplumun demokratikleşme ideallerini sanal kamusal uzamda hipergerçek idealler haline getirerek, çok sesli bir görüntünün ardında tek sesliliği yeni biçimlerle üretecektir. Yeni medya ticarileştikçe kapitalizmle göbek bağını kesemeyecek, bireylerin tüketim kültürüne köleliğini artıracaktır. Yeni medya kültür endüstrisinin üretim mantığını benimsedikçe metalaşma sürecini hılandıracak, bireylerin özel hayatlarını umumileştirerek kamusal alanı kamusal olmayan deneyimlerle işgal edecektir. Yeni medya söz ve eylemin gösteriye dönüştüğü, kamusal dekoratifli bir sahneden öteye gidemeyecektir.

Yeni medya-kamusal alan ilişkisine olumlu yaklaşanlar için ise yeni medya, modern-siyasal alandan dışlanmış, geleneksel medya imkânlarıyla kendilerini ifade edemeyen, ötelenmiş bireyler ile hiçbir dışlayıcılığa maruz kalmamakla birlikte sosyal hayatta "ben'de varım diyenlerin hakeza bilcümlenin "ölümsüzlük" aracı olarak da kullanılabilir. Yeni medya bireylere kamusal faaliyetlerinde ihtiyaç duydukları bilgiye ulaşmaları ve geniş kitlelere yaymaları konusunda oldukça verimli bir araçtır. Bu avantajla yeni medya bireylerin kamusal iletişimde karşllkk konuşma, kamusal müzakere, ortak karara ulaşabilmelerini, kamusal eylem ayağında düzenlenen sanal protestoların sokak eylemleriyle buluşabilmelerini sağlayacaktır. Demokratikleşme sürecinde yeni medyanın kamusal alan olma potansiyeli devletin nüfuz alanına bırakılmış kamusal konulara müdahil olabilmesi ile açığa çıkacaktır. Bu bağlamda "siber uzamın yeni kamusal alanlarında yeni bir teknopolitika yeşerebilir” diyen D. Kellner'in taşıdığı umut ile yeni medyanın gelecekteki konumu tanzim edilmelidir.

Geçmişte ve şu anda olduğu üzere gelecekte de sosyal, iktisadi, siyasal sorunlara ilişkin kamusal mücadele klasik kamusal alanlarda (sokakta, üniversitede, işyerinde, mecliste....) başarı elde edecektir. $\mathrm{Bu}$ başarının yakalanmasında yeni medyanın varlığı hesaba katılarak düzenlemeler yapılmalıdır. $\mathrm{Bu}$ ise yeni medyanın iktidar elitlerinin hegemonyasını pekiştirmek için mi yoksa insani taleplerin müzakere edildiği kamusal alana hizmet etmek için mi kullanılacağına karar vermekle mümkündür. Şüphesiz ki bu karar, akıl-iradesorumluluk sahibi tek varlık olan insanın evrensel vicdanında alınacaktır. 


\section{SUMMARY}

Being the founder of social life human is independent from his creation at a certain extent and even he's an authority who rules it. But ironically he is dependent to his creation, has demands from it, indigent to his grace and has the status of a slave, a vassal and a citizen. Regardless of the position of human to natural or social entity, the tool which correlates them is communication. Because of that humankind developed their communication tools and styles through historical process. These days communication came in connection with information technologies to a high level. The virtual communication platform with invention of computer and internet which gathers all oral, written, imagery and auditorial communication languages and surpasses borders bonded to time and space over a cyber web named "new media". Even the name and the style of the communication can differ to the tool the purpose of the communication remains the same. Understanding environments that mankind divided into private and public, deliver the requests that belongs to any of them and making them active actors in social interaction are basic purposes of communication. Dividing of human living environment into private and public sphere shown itself in Antic Greek City State. Private-public sphere distinction that absorbed from Ancient Greek idea shown itself in every era. However meaning, function, represented environments, actors and relations of private and public sphere concept constantly changed. The process of these concepts usage styles in contemporary societies are based on the 18th century West consideration and advancement on this geography. In this context "public sphere" is a field that open to participate and observe, everyone responsible to each other but no one interfere to other, principles of equality-freedom are valid and a field to expressing self-perceiving other. The models of modern public sphere fed by Ancient Greek philosophy tradition conributing with important arguments to our democratic ideals and practical lives had taken serious critisizm lately. Modern public sphere models weren't oblivious to critisizm and went to reformation. But because of their persistency on their basic principles they become insufficent to nowadays public sphere problems. The ultimate objective of struggle that is existing between different ideas is making public a value among political authority, meeting the public demands in participatory democracy. If there is bond between fate of humanity and democracy, every tool needs to be used in order to make it stronger. Therefore in today's network societies new media's position and the function that it is going to take over needs to be disscussed. At this criticisim the dichotomous structure of new media communication needs to be seriously discussed. Aim of this study is analizing the potential of new media's being "public sphere" and discharging the concept of 'public shere'. In this analysis separately on public sphere, discussion over new media or literature focused on relation between them and describing current situation has taken basis as a method. The new media with its new shape is going to impede pluralistic democracy applications by undertaking duty of being one of the print tools of dominant 
structures. Or the new media, as a new public sphere of cyber extension is going to supply everybody to participate in politics area with their own languages spryly in a free and equal way, like especially opponent public area models imagine. Now it is difficult to arrive at a certain decision about the relation of new media, public sphere and democracy. Ultimately the new media is a mass medium which has got advantages and disadvantages. The message of this tool will be determined by people. The time will show perfectly how structure of double values of the new media will evolve; however, with this shape the new media is a digital area in which people use a hypertext language. 


\section{KAYNAKÇA}

ARENDT, Hannah (2013). İnsanlık Durumu. çev. Bahadır Sina Şener. İstanbul: İletişim Yay. 7. bs.

AYDIN, Mustafa (1998). "Kamusalın Dönüşümünün Dinsel ve Siyasal Sonuçları". Tezkire Dergisi (13): 105-130.

AYDIN, Mustafa (2002). "Bir Siyasal Mahremiyet Alanı Olarak Kamusal ve Kilık Kiyafet Sorunu". Umran Dergisi (96): 77-81.

AYDOĞAN, Filiz-KIRIK, Ali Murat (2012). "Alternatif Medya Olarak Yeni Medya". Akdeniz Üniversitesi İletişim Fakültesi Dergisi (18): 58-69.

BENHABIB, Seyla (1996). "Kamu Alanı Modelleri”. Cogito Dergisi (8): 238258.

BERKTAY, Fatmagül (2015). "Hannah Arendt: 'Çoğulluk, Yeryüzünün Yasasıdır”. Kamusal Alan. ed. Meral Özbek. İstanbul: Hil Yay. 707-716. 3. bs.

BUCSTEIN, Hubertus (1997). "Bytes That Bite: The Internet and Deliberative Democracy". Constellation 4 (2): 248-264.

BUDAK, Hatice (2016). Yeni Çağ Yeni Medya ve Mahremiyetin Yeni Sınırları. Doktora Tezi. Konya: Selçuk Ü.

ÇAHA, Ömer (1998). "İdeolojik Kamusalın Sivil Kamusala Dönüşümü”. Doğu Batı Dergisi (5): 73-93.

ÇAYCI, Berk-KARAGÜLLE, Ayşegül Elif (2014). "Mobil İletişim Teknolojileriyle Değişen Örgütlenme Biçimleri: Ağlarda Örgütlenen Toplumsal Hareketler". Journal of Yasar University 9 (36): 6371$6380 . \quad$ http://journal.yasar.edu.tr/wpcontent/uploads/2014/12/10_Vol_9_36.pdf [18.03.2016].

DEMIR, Songül (1998). "Kamusal Alanın Belirlenmesinde Ben İle Ötekinin Yeri”. Doğu Batı Dergisi (5): 209-212.

GÖKÇE, Orhan (2012). "Yeni Medya-Kamuoyu-Demokrasi". Hepimiz Globaliz Hepimiz Yereliz. ed. Edibe Sözen. İstanbul: Alfa Yay. 37-54.

GÖKER, Göksel (2015). "İletişimin Mcdonaldlaşması: Sosyal Medya Üzerine Bir Inceleme". Turkish Studies, International Periodical For The Langues, Literatüre and History of Turkish or Turkic 10 (2): 389-410.

GÜÇDEMIR, Yeşim (2003). "Bilgisayar Ağları İnternetin Gelişimi ve Bilgi Kirlenmesi”. İstanbul Üniversitesi İletişim Fakültesi Dergisi (17): 371-378.

HABERMAS, Jurgen (1997). Kamusallığın Yapısal Dönüşümü. çev. Tanıl BoraMithat Sancar. İstanbul: İletişim Yay. 
HABERMAS, Jurgen (2015). "Kamusal Alan". Kamusal Alan. ed. Meral Özbek. İstanbul: Hil Yay. 95-102. 3. bs.

HANSEN, Miriam (2015). "Yirmi Yılın Ardından Negt ve Kluge'nin "Kamusal Alan ve Tecrübe"si: Değişken Karışımlar ve Genişlemiş Alanlar”. Kamusal Alan. ed. Meral Özbek. İstanbul: Hil Yay. 141-176. 3. bs.

HASDEMIR, Tuba-COŞKUN, M. Kemal (2008). "Kamusal Alan ve Toplumsal Hareketler". Ankara Üniversitesi İletişim Fakültesi Dergisi (18): 58-69.

KARADAĞ, Ahmet (2003). "Kamusal Alan Modelleri: Çoğulcu Perspektiften Bir Değerlendirme”. Ankara Üniversitesi S.B.F. Dergisi 58 (3): 171-195.

KARAGÖZ, Kezban (2013). "Yeni Medya Çağında Dönüşen Toplumsal Hareketler ve Dijital Aktivizm Hareketleri”. Iletişim ve Diplomasi Dergisi (1): 132-157.

KARAKAŞ, Halime (1998). "Sivil İtaatsizlik Ne Kadar İtaatsiz?". Doğu Batı Dergisi (5): 157-176.

KEJANLIOĞLU, D. Beybin (2015). "Medya Çalışmalarında Kamusal Alan Kavramı". Kamusal Alan. ed. Meral Özbek. İstanbul: Hil Yay. 837-860. 3. bs.

KELLNER, Douglas (2015). "Tabandan Küreselleşme: Radikal Demokratik Bir Teknopolitikaya Doğru”. Kamusal Alan. ed. Meral Özbek. İstanbul: Hil Yay. 861-881. 3. bs.

KEYMAN, E. Fuat (1998). "Kamusal Alan ve Cumhuriyetçi Liberalizm: Türkiye'de Demokrasi Sorunu”. Doğu Batı Dergisi (5): 57-72.

KÜÇÜKŞEN, Kübra (2016). "Perception of Gender Equality in New Media". International Journal of Human Sciences 13 (1). 1285-1292. https://www.jhumansciences.com/ojs/index.php/IJHS/article/view/3565 doi:10.14687/ijhs.v13i1.3565 [30.06.2016].

ÖZBEK, Meral (2015a). "Kamusal Alanın Sınırları". Kamusal Alan. ed. Meral Özbek. İstanbul: Hil Yay. 21-90. 3. bs.

ÖZBEK, Meral (2015b). "Kamusal-Özel Alan, Kültür ve Tecrübe". Kamusal Alan. ed. Meral Özbek. İstanbul: Hil Yay. 601-658. 3. bs.

ÖZENSEL, Ertan (2015). "Sosyal Medyanın Mısır Devrimindeki Rolü”. Sosyoloji Dergisi (5): 69-83.

ÖZGÜL, Gönül Eda (2012). "Bir Görme Biçimi Olarak Yeni Medya: Kamusal Bir Alan İmkanının Araştıılması”. Journal of Yasar Unıversity 26 (7): 45264547.http://journal.yasar.edu.tr/wpcontent/uploads/2012/10/26_Sayi_8_ma kale gonul eda_ozgul.pdf [18.03.2016]. 
SENNETT, Richard (1996). Kamusal İnsanın Çöküşü. çev. Serpil DurakAbdullah Yılmaz. İstanbul: Ayrıntı Yay.

SÖZEN, Edibe (2012). "Sosyal Medyanın Arkeolojisi". Hepimiz Globaliz Hepimiz Yereliz. ed. Edibe Sözen. İstanbul: Alfa Yayın. 1-36.

ŞEN, Ercan (1998). "Kamusal Alan ve Özgürlük”. Tezkire Dergisi (13): 63-70.

TiMisi, Nilüfer (2003). Yeni İletişim Teknolojileri ve Demokrasi. Ankara. Dost Kitabevi.

UÇKAN, Özgür (2012). Dijital Aktivizm mi, Aktivizm mi?. $\quad$ https://spotdergi.wordpress.com/2012/05/30/dijital-aktivizm-miaktivizm-mi [01.05.2014].

ÜNÜVAR, Kerem (1998). "Osmanlı'da Bir Kamusal Mekân: Kahvehaneler". Doğu Batı Dergisi (5): 186-196.

VILLA, Dana R. (1996). "Postmodernlik ve Kamusal Alan". Cogito Dergisi (8): 259-274.

YAĞAN, Uğur (2013). "Teknoloji, Kamusal Alan ve Sosyal Medya: Üniversite Öğrencilerinin Sosyal Medya Kullanımı ve Politik Katılım Üzerine Amprik Bir Çalışma". İletişim Araştırmaları Dergisi 11 (1-2): 123-153. 